\title{
Nepal-India Relationship After The Rise of Modi
}

\author{
Dr. Ishwori Prasad Kandel*
}

\begin{abstract}
This paper has attempted to define Nepal, being a sovereign country would like to deal with India on an equitable basis. Geographically, culturally and economically, Nepal is closer to India. Nepal also realizes that it can't ignore its southern neighbor India. The Republic of India and the Federal Democratic Republic of Nepal initiated their relationship with the 1950 Indo-Nepal Treaty of Peace and Friendship and accompanying secret letters that defined security relations between the two countries, and an agreement governing both bilateral trade and trade transiting Indian territory. The Indo-Nepal border is open; Nepalese and Indian nationals may move freely across the border without passports or visas and may live and work in either country. However, Indians aren't allowed to own land-properties or work in government institutions in Nepal, while Nepalese nationals in India are allowed to work in Indian government institutions (except in some states and some civil services the IFS, IAS, and IPS). After years of dissatisfaction by the Nepalese government, India in 2014, agreed to revise and adjust the treaty to reflect the current realities, however, the modality of adjustment hasn't been made clear by either side. Due to geographical proximity, socio-cultural affinity and economic dependence of Nepal, India has strong influence on Nepal and its policy decisions.
\end{abstract}

Modi's first visit to Nepal in August 2014 as part of his 'neighbourhood first' policy was highly successful. He was the first foreign leader to address the Constituent Assembly - the body tasked with drafting Nepal's new constitution. His remarks drew widespread praise from all Nepalese political parties and seemed to promise a new beginning in India-Nepal relations. Minister Narendra Modi had expressed its displeasure at Nepal's constitution, a position made clear in a series of statements issued by Ministry of External Affairs (MEA) in New Delhi. Citing MEA sources, Indian Express even circulated a seven-point demand for amendments to the constitution, within days of its promulgation. With the election of nationalistic leader K P Oli as prime minister in Nepal, the rift between Delhi and Kathmandu was widened, and lead to a massive humanitarian crisis, as shortages of fuel, medicines, and essential supplies become acute across Nepal, with no sign of reconciliation in sight.

Keywords: Humanitarian, Multidimensional , Relationship \& Jana-Andolan.

* Dr.Kandel is an Associate professor at the Central Department of Political science, T.U., Kirtipur. 


\section{Statement of The Problem}

This paper will focus Nepal and India Relationship after the rise of Modi and find answers the fallowing questions.

a. What is the present day relation between the Nepal and India ?

b. What is political impact of foreign policy ?

\section{Objective of The Study}

\section{The Specific Objectives Were As Follows:}

a. To explain the present day relation between the Nepal and India ?

b. To examine the political impact of foreign policy ?

\section{Research Methodology}

The methodology for the proposed study would utilize both primary and secondary sources. The primary sources of data would include documents of the government agencies, press release, joint statements and organizational reports and the secondary source of data will include books, news reports, various journal articles, newspaper clippings, and various academic papers. The research is primarily based on secondary data which includes published books, research papers and internet websites related to the problem. Various books, research papers and internet websites has been consulted to understand the Nepal India relationship. For the study of the concerned subject, the researcher has taken a qualitative approach and thus, descriptive and analytical methods have been chosen.

\section{Introduction}

Nepal faces a huge trade deficit with India. Nepal needs to work to minimize that deficit. The two countries share an open border. They need to make sure that the open border is not misused by criminals, drug traffickers, human traffickers and counterfeit currency racketeers. Nepal-India relations are so multidimensional that we cannot say we will only focus on certain areas. The fact of the matter is Nepal has to develop good relations with India to realize its goal of prosperity (Jaisawal, 2012 : 125). India-Nepal relations hit a new low in 2015, under Oli’s government, when India voiced concerns over Nepal's then-newly promulgated constitution and instituted an unofficial blockade that prevented crucial supplies from entering the country. Oli, who was then leading the government, vehemently criticized the blockade and there was huge support in Nepal for his stance. Oli also signed a trade and transit agreement with China with the goal of ending India's monopoly over Nepal's supply of daily essentials. After this, the Indian establishment always blamed Oli 
for playing the "China card” and creating anti-Indian sentiments in Nepal (Dahal, 2064 : 34).

The 1950 treaty and letters exchanged between the Nepal and government, stated that "neither government shall tolerate any threat to the security of the other by a foreign aggressor" and obligated both sides "to inform each other of any serious friction or misunderstanding with any neighboring state likely to cause any breach in the friendly relations subsisting between the two governments." These accords cemented a "special relationship" between India and Nepal (Pandey, 2005 : 56). The treaty also granted Nepalese, the same economic and educational opportunities as Indian citizens in India, while accounting for preferential treatment to Indian citizens and businesses compared to other nationalities in Nepal. . Nepal and India have open borders. Apart from the economic and trade interest of both the neighboring countries, they also have interest in containing the US influences in the region. Both the countries take each other as competitors and lack trust deficit after the 1962 war on border dispute. The democratic era started in Nepal in 1990 after the democratic movement Jana - Andolan I. The 1990 movement brought complete change in foreign policy of Nepal Government of India provides development assistance to Nepal, focusing on creation of infrastructure at the grass-root level, under which various projects have been implemented in the areas of infrastructure, health, water resources, education and rural \& community development (Prasad, 1989 : 165). In recent years, India has been supporting projects in Nepal for development of infrastructure._Nepal - India's politically fragile northern neighbour is closely watching events unfold in the Asian giant to the south following the landslide election victory of Hindu nationalist Bharatiya Janata Party led by Narendra Modi. Mindful of the key role played by India in its political transition and New Delhi's immense leverage in the country, observers in Nepal are seeking clues to likely policy in the region (Glaser, 1993 : 321). Meanwhile, many in the country - the world's only Hindu monarchy until it was abolished in a stunning vote by the constituent assembly in 2008 - have high hopes on Modi's victory prompting a revival of Hinduism."The victory of Narendra Modi is good news for us, we are sure we will receive his goodwill," said Basudev Shastri, a pro-Hindu activist with National Religion Awareness Campaign. "I think we Nepalis will succeed in reclaiming Nepal as a Hindu nation." Modi in his first reaction on foreign affairs, expressed commitment to strengthening relations with Nepal. "Nepal is an old and deeply valued friend," he wrote on Twitter.

\section{Current Status of Nepal-India Political Impact}

Nepal and India enjoy excellent bilateral ties. Founded on the age-old connection of history, culture, tradition and religion, these relations are close, comprehensive and 
multidimensional and are pronounced more in political, social, cultural, religious and economic engagements with each other. To add up the formal flavor to such historic relations, the two countries established diplomatic relations on 17 June 1947. The unwavering commitment to the principles of peaceful coexistence, sovereign equality, and understanding of each other's aspirations and sensitivities has been the firm foundation on which our bilateral relations have been growing further. Nepal's solemn desire to cultivate and foster the cordial and friendly ties with its neighboring countries are reflected in its long standing position of not allowing its territory to be misused by any elements inimical to India and also expects same sort of reciprocity and assurances from her. The open border between the two countries remains a unique feature of our relations. Frontier without restriction has greatly facilitated the free movements of our people to each other's territory and enhanced interactions (Khanna, 2003 : 324).

\section{Political Relations}

Nepal-India relations are, in essence, much more than the sum of treaties and agreements concluded between the two countries. The frequent high level visits by the leaders of the two countries at different points of time and the interactions constitute the hallmark of the ties between the two countries (Manandhar, 2007 : 164). Furthermore, such visits have helped promote goodwill, trust, understanding and cooperation between the two countries and, have injected fresh momentum to further consolidate age-old and multi-faceted bilateral relations of friendship and cooperation on a more mature and pragmatic footing. Nepal occupies an important position between India and China because India and China's paramount concern in Nepal is related to security and stability (Bhattarai, 2005 : 49). Kamal Dev Bhataral in his article "Resetting India-Nepal Relations" published in the diplomat dated April 10, 2018 explains the change in Nepal India relationship after the rise of modi in India. Moreover he defines the relation as a crisis that occurred with the arrival of Modi as PM in India. India's disagreement in Nepal's constitution and the economic blockade that fallowed soon created anger specially in Nepalese side prompting it to look north. India's act made Nepal think as interference to their sovereignty and created gap between the countries. He describes as the policy or rather failed policy of Modi to create balanced relationship with neighboring, provides the in depth knowledge about two neighboring countries regarding cultural ties, education, diplomatic relation, defiance exchanges, investment of countries in each other's territory, trade relation and high-level exchange of visit. It has clearly brought out the requirement of good relationship between the two neighboring friends. As emphasized by Prime Minister Narendra Modi, India will have to focus on connectivity as a leverage to increase its strategic influence in the neighborhood. 
For almost half a century, India’s economic insulation transformed its borders into barriers (Muni, 1995 : 213).

\section{Exchange of Visits}

- At the cordial invitation of the then President of India Shri Pranab Mukherjee, The Rt. Hon’ble Bidya Devi Bhandari, President of Nepal paid a State Visit to India in April 2017.

- Ram Baran Yadav, as the first President of Nepal, paid a State visit to India in February 2010 at the invitation of Ms. Pratibha Devisingh Patil, the then President of India.

- At the invitation of His Excellency Shri Narendra Modi, Prime Minister of India, The Rt. Hon'ble K P Sharma Oli, Prime Minister of Nepal, paid a State Visit to India on 6-8 April 2018. Earlier also, he had paid a State Visit to India in February 2016.

- At the invitation of the Prime Minister of India, His Excellency Shri Narendra Modi, the then Prime Minister of Nepal Mr. Sher Bahadur Deuba paid a State Visit to India in August 2017.

- The then Prime Minister of Nepal, Mr Pushpa Kamal Dahal 'Prachanda' paid a State Visit to India in September 2016 and also visited India in October 2016 to participate in the BRICS-BIMSTEC Outreach Summit in Goa, India.

- The then Prime Minister of Nepal Mr. Sushil Koirala visited India to attend the swearingin ceremony of the Prime Minister elect Shri Narendra Modi in May 2014.

- The then Deputy Prime Minister and Minister for Foreign Affairs Mr. Krishna Bahadur Mahara visited India in July 2017 at the invitation of Her Excellency Smt Sushma Swaraj, Minister of External Affairs of India.

- Then Minister for Foreign Affairs Dr. Prakash Sharan Mahat visited India in October 2016 leading a Nepali delegation to participate in the 4th meeting of Nepal-India Joint Commission

- Then Minister for Foreign Affairs Dr. Prakash Sharan Mahat visited India in September 2016.

- The then Deputy Prime Minister and Minister for Foreign Affairs Mr. Kamal Thapa visited India in November 2015.

\section{From India:}

- The then President of India Shri Pranab Mukherjee paid a State Visit to Nepal in November 2016.

- At the invitation of the Prime Minister of Nepal, The Rt. Hon'ble K P Sharma Oli, the Prime Minister of India His Excellency Shri Narendra Modi paid a State Visit to Nepal from 11 to 12 May 2018. 
- At the invitation of then Prime Minister Mr. Sushil Koirala, the Prime Minister of India His Excellency Shri Narendra Modi paid an official visit to Nepal in August 2014.

- His Excellency Prime Minister Modi also visited Nepal in November 2014 to participate in the $18^{\text {th }}$ SAARC Summit.

- At the invitation of the then Foreign Minister Mr. Mahendra Bahadur Pandey, the External Affairs Minister of India Smt Sushma Swaraj paid an official visit to Nepal in July 2014 to participate in the third meeting of the Nepal-India Joint Commission.

- Her Excellency Smt Swaraj visited Nepal in June 2015 to participate in the International Conference on Nepal's Reconstruction and in August 2017 to participate in the $15^{\text {th }}$ BIMSTEC Ministerial Meeting.

The recent exchange of State Visits by the Prime Ministers of Nepal and India in April and May 2018 has contributed to taking the bilateral relations to newer heights on the basis of equality, mutual trust, respect and benefit. Apart from taking effective measures for the implementation of all the agreements and understandings reached in the past, the need for reinvigorating the existing bilateral mechanisms to promote cooperative agenda across diverse spheres has been underscored. Both sides have agreed to advance new partnership in agriculture, expand rail linkages connecting Kathmandu to Raxaul with India's financial support, and develop inland waterways for the movement of cargo providing additional access to sea for Nepal. It has also been agreed to address outstanding matters in a stipulated timeframe, with the objective of advancing cooperation in all areas (Muni, 1995 : 87).

\section{.Nepal-India Economic Relations}

India has been a key development partner of Nepal. The latter received strong support and solidarity from the people and Government of India in advancing its home-grown peace process as well as in the process of writing the Constitution through the elected Constituent Assembly. Following the massive earthquakes in Nepal in April and May 2015, India promptly offered helping hands (Thapa, 2005 : 156). The Government of India has also been substantially supporting Nepal's reconstruction efforts. The Indian cooperation started in 1952 with the construction of an air-strip at Gaucharan. Since then, India has been assisting primarily in the areas of infrastructure development and capacity development of human resources in Nepal (Dahal, 2064 : 231). Such assistance received from India has helped supplement the developmental efforts of Nepal. India's economic assistance to Nepal has grown manifold in the past few decades, particularly since the restoration of multiparty democracy in Nepal in 1990. As agreed during the State Visit to India of then Prime Minister of Nepal Mr. Pushpa Kamal Dahal 'Prachanda' in September 2016, a Nepal-India Joint Oversight Mechanism has been constituted co-chaired by the Foreign Secretary of 
Nepal and the Indian Ambassador to Nepal to review the progress made and resolve issues in the implementation of the projects under India's economic and development cooperation. The Mechanism meets once every two months (Bhatt, 1996 : 23).

\section{Projects Undertaken with India’s Economic Assistance}

B.P. Koirala Institute of Health Sciences, Dharan; Emergency and Trauma Centre at Bir Hospital, Kathmandu; and Manmohan Memorial Polytechnic at Biratnagar are some of the flagship projects completed and operationalzed under the Indian assistance. In the International Conference on Nepal's Reconstruction held in Kathmandu in June 2015, the Government of India pledged a fund of US\$ 250 million grant and US\$750 million soft loan. Agreements have already been signed for both grant and loan (Muni,1995 : 76). List of projects have been identified for the utilization of the grant while projects are being finalized for the use of Line of Credit. In addition to two past lines of credit (US\$ 100 million and US\$ 250 million), His Excellency Prime Minister of India Modi announced during his visit to Nepal in August 2014 another line of credit of US\$ 1 billion to be utilized to finance development projects chosen by Nepal. The Government of Nepal finalized the projects (Ramakant, 1976 : 177). The modality of contracting these projects is being worked out.

\section{Conclusion}

Nepal and India share a unique relationship of friendship and cooperation characterized by open borders and deep-rooted people-to-people contacts. There has been a long tradition of free movement of people across the borders sharing family ties and culture. There are regular exchanges of high level visits and official interactions between India and Nepal. In 2014, Prime Minister Modi visited Nepal twice - in August for a bilateral visit and in November for the SAARC Summit. Despite the close linguistic, marital, religious, and, cultural ties, at people to people level between Nepalese and Indians, since late 2015, political issues and border disputes have strained relations between the two countries with anti-Indian sentiment growing amongst the government and people of Nepal after the rise of Modi in India. Further because of border disputes between the two countries, a boundary agreement hasn't yet been ratified by either government. This changes the fundamental nature of India-Nepal relations and requires both sides to recalibrate their "special" relationship. To succeed in their endeavor to chart a mutually beneficial and sustainable partnership, both countries will have to take a deep look at history to avoid past mistakes. while dealing with its smaller neighbors, India will have to abandon the archaic principle of right of first refusal and invest in expanding its capacity of first delivery. New Delhi never communicated such concerns in the first place, or did not articulate them 
forcefully enough. New Delhi will have to communicate such expectations more clearly. History shows that India will often assume that the Nepalese government is deliberately acting against its advice when, in fact, New Delhi never communicated such concerns in the first place, or did not articulate them forcefully enough. High level visits mark the advent of a new phase in India-Nepal relations, with a more confident Kathmandu engaging India eye to eye. Similarly, the visit also confirms the normalization of the relationship after some hiccups since 2014 and India's willingness to focus on transactional business with special emphasis on connectivity as a credible partner.

\section{References}

Arpi, Claude (1999). “ The Fate of Tibet” Har-Anand Publication Pvt. Ltd.

Bhattarai, Rajan (2005), Geopolitics of Nepal and Internal Response to Conflict Transformation, Kathmandu: FFP Publications.

Bhatt, S.C. (1996). The Triangle IndiaNepalChina a Study of Treaty Relations, Delhi: Gyan Publishing.

Bhattarai, Rajan (2005). Geopolitics of Nepal and Internal Response to Conflict Transformation, Kathmandu: FFP Publications.

Dahal, Ramkumar (2064). Nepal and International Relations, Kathmandu, Dikshyanta Prakashan.

Dutta,V.P (1993). India's Foreign Policy, Vikas Publishing House.

Glaser, Bonnie S, (1993). China's Security Perceptions: Interests and Ambitions, Asian Survey. Jaisawal, Pramod (2012). Nepal-China Relations 1990-2009, Lambert Academic Publishing.

Khanna, V. N. (2003). Foreign Policy of India. New Delhi: Vikas Publishing House.

Manandhar, V K (2007). Cultural and Political Aspects of Nepal - China Relations, New Delhi: Adroit Publishers.

Muni, S. D. (1995). India and Nepal, a Challenging Relationship. Delhi: Konark Publishers Ltd. Pandey, Nishchal N.(2005). Nepal-China Relations, Kathmandu, Institute of Foreign Affairs.

Prasad, Shahi Bhushan, (1989). The China factor in Indo-Nepalese relations 1955-72. New

Delhi: Janaki Prakashan.

Ramakant (1976). Nepal - China and India, New Delhi: Abhinav Publication.

Thapa, H. B. (2005). Economic Dimention of Nepal- China Relations. Kathmandu: Institute of Foreign Affairs. 